\title{
Penyerapan Anggaran Belanja Langsung Pada Dinas Kesehatan Kabupaten Bandung
}

\author{
${ }^{1}$ Sahya Anggara, ${ }^{2}$ Pilawati \\ ${ }^{1}$ Administrasi Publik Fakultas Ilmu Sosial dan Ilmu Politik UIN Sunan Gunung Djati Bandung; \\ sahyaanggara@uinsgd.ac.id \\ ${ }^{2}$ Administrasi Publik, Fakultas Ilmu Sosial dan Ilmu Politik UIN Sunan Gunung Djati Bandung; \\ pilawati09@gmail.com
}

\begin{abstract}
The purpose of this study is to analyze, study and find out how the absorption of direct expenditure budget at the Bandung District Health Office 2017 Fiscal Year. In measuring the budget absorption variable, the author uses Halim's theory of budget absorption which includes budget, budget absorption, supporting factors and obstacles to budget absorption. The research approach used is qualitative research type description. Data collection techniques were carried out by direct observation, in-depth interviews, and document studies. Data analysis techniques using the theory of Miles and Huberman which consists of three activities namely Data Reduction, Data Presentation, Drawing Conclusions. The results showed that based on three-dimensional indicators the absorption of direct budget in general has been going well. But there are still a number of things that need to be improved, namely regarding the approval of the budget that has not been timely, the lack of human resources (employees) and there are programs that have not been achieved effectively and efficiently so that it affects the absorption of direct expenditure that is not yet optimal. So that the Bandung District Health Office must make efforts to increase and optimize budget absorption by means of approving budgets in a timely manner, proposing an increase in the number of employees and conducting socialization to employees about the budget that will be used in carrying out any program activities that have been previously determined so that the absorption of the budget can be absorbed immediately optimally.
\end{abstract}

Keywords: Budgeting System, Direct Expenditure, Budget Absorption

\section{Pendahuluan}

Undang-Undang Otonomi Daerah dan Undang-Undang No. 33 Tahun 2004 tentang Perimbangan Keuangan antara Pemerintah Pusat dan Daerah telah menciptakan perubahan mendasar terhadap pelaksanaan pemerintahan. Suatu perubahan dalam hal pengelolaan keuangan negara dan juga menjadi langkah awal kemunculan otonomi daerah. Keuangan negara merupakan setiap hak dan kewajiban negara yang dapat dihitung dengan uang, dan segala sesuatu baik berupa uang maupun berupa barang yang dapat dijadikan milik negara berhubung dengan pelaksanaan hak dan kewajiban tersebut. Sejauh ini, kemampuan dan kinerja pemerintah dalam perencanaan dan pengendalian keuangan dirasakan masih terlalu lemah. Pada umumnya lembaga pemerintah belum menjalankan fungsi dan peranannya secara efektif dan efisien. Sementara itu, analisis untuk mengetahui tingkat biaya untuk setiap kegiatan masih jarang dilakukan. Perencanaan anggaran yang lemah pada akhirnya akan memunculkan kemungkinan underfinancing atau overfinancing, yang kesemuanya akan mempengaruhi tingkat efisiensi dan efektivitas unit kerja pemerintah. Anggaran sebagai alat untuk melaksanakan strategi organisasi harus dipersiapkan sebaikbaiknya agar tidak terjadi bias atau 
penyimpangan. Penyerapan anggaran merupakan membandingkan anggaran dengan realisasinya. Fenomena rendahnya penyerapan anggaran menjadi isu yang menarik di kalangan pemerintah dan masyarakat.

Dinas Kesehatan Kabupaten Bandung merupakan bagian dari Satuan Kerja Perangkat Daerah (SKPD) Pemerintah Kabupaten Bandung, Dinas tersebut bergerak di bidang pelayanan kesehatan publik. Di dalam Laporan Kinerja Instansi Pemerintah (LKIP) Dinas Kesehatan Kabupaten Bandung Tahun 2017, dijelaskan bahwa seluruh program atau kegiatan yang dilaksanakan oleh Dinas Kesehatan Kabupaten Bandung sejalan dengan Visi Kabupaten Bandung Tahun 2016 s/d 2021 yaitu "Memantapkan Kabupaten Bandung yang Maju, Mandiri dan Berdaya Saing, melalui Tata Kelola Pemerintahan yang Baik dan Sinergi Pembangunan Perdesaan, Berlandaskan Religius, Kultural dan Berwawasan Lingkungan”.

Sektor kesehatan merupakan sektor penting dalam mencapai visi tersebut. Pengembangan kebijakan pembangunan kesehatan sangat penting mengingat penyelenggaraan pembangunan kesehatan pada saat ini semakin kompleks. Sebagai penjabaran dari Visi tersebut maka di dalam Rencana Strategis Dinas Kesehatan Kabupaten Bandung 2016-2021, pada Tahun 2017 terdapat sasaran prioritas yaitu meningkatnya penyediaan layanan kesehatan. Dalam menunjang keberhasilan dalam sektor kesehatan, maka Dinas Kesehatan Kabupaten Bandung mendapatkan Pagu Anggaran Belanja Langsung sebesar Rp. 365.116.587.042,-. Pagu anggaran belanja langsung tersebut dilaksanakan untuk membiayai empat sasaran strategis dengan Sembilan indikator kerja yang ada pada Dinas Kesehatan Kabupaten Bandung Tahun 2017, empat sasaran strategis tersebut yaitu:

Tabel 1.1

Realisasi Kinerja dan Anggaran Pada Tahun 2017

\begin{tabular}{|c|c|c|c|c|c|}
\hline No & $\begin{array}{l}\text { Sasaran } \\
\text { Strategis }\end{array}$ & $\begin{array}{l}\text { Indikator } \\
\text { Kinerja }\end{array}$ & Anggaran & Realisasi & $\begin{array}{l}\% \\
\text { Penyerapan }\end{array}$ \\
\hline \multirow[t]{2}{*}{1.} & \multirow[t]{2}{*}{$\begin{array}{l}\text { Optimalnya } \\
\text { Penyediaan } \\
\text { Layanan } \\
\text { Kesehatan }\end{array}$} & $\begin{array}{l}\text { Indeks } \\
\text { Kepuasan } \\
\text { Masyarakat } \\
\text { (KM) Bidang } \\
\text { Kesehatan }\end{array}$ & 41.986 .424 .513 & 34.433 .120 .088 & 82,01 \\
\hline & & $\begin{array}{l}\text { Cakupan } \\
\text { Pelayanan } \\
\text { Kesehatan } \\
\text { Dasar bagi } \\
\text { Masyarakat } \\
\text { Miskin } \\
\end{array}$ & 36.236 .424 .316 & 32.183 .850 .125 & 88.82 \\
\hline \multirow[t]{3}{*}{2.} & \multirow{2}{*}{$\begin{array}{l}\text { Menurunnya } \\
\text { Angka } \\
\text { Kesakitan dan } \\
\text { Kematian }\end{array}$} & $\begin{array}{l}\text { Umur Harapan } \\
\text { Hidup (UHH) }\end{array}$ & 200.952 .044 .406 & 141.365 .233 .362 .67 & 70,35 \\
\hline & & $\begin{array}{l}\text { Angka } \\
\text { Kematian Bayi }\end{array}$ & 78.611 .351 .374 & 28.835 .417 .298 & 36,68 \\
\hline & Akibat & $(\mathrm{AKB})$ & & & \\
\hline
\end{tabular}




\begin{tabular}{|c|c|c|c|c|c|}
\hline & $\begin{array}{l}\text { Penyakit } \\
\text { Menular dan } \\
\text { Tidak Menular }\end{array}$ & $\begin{array}{l}\text { Prevalensi } \\
\text { Balita Stunting } \\
\text { pada Anak } \\
\text { Baduta (bawah } \\
\text { dua tahun) } \\
\end{array}$ & 955.629 .300 & 939.722 .300 & 98,34 \\
\hline \multirow[t]{2}{*}{3.} & \multirow{2}{*}{$\begin{array}{l}\text { Meningkatnya } \\
\text { Sanitasi Dasar, } \\
\text { Lingkungan } \\
\text { Sehat dan } \\
\text { Perilaku Hidup } \\
\text { Sehat di } \\
\text { Masyarakat }\end{array}$} & \begin{tabular}{l}
\multicolumn{2}{l}{ Universal Akses } \\
$100,0,100 \quad$ di \\
tahun 2019
\end{tabular} & 1.370 .000 .000 & 1.283 .984 .525 & 93,72 \\
\hline & & $\begin{array}{l}\text { Persentase } \\
\text { PHBS pada } \\
\text { Rumah Tangga }\end{array}$ & 1.006 .135 .000 & 788.200 .000 & 78,34 \\
\hline \multirow[t]{2}{*}{4.} & \multirow[t]{2}{*}{$\begin{array}{l}\text { Meningkatnya } \\
\text { Tata Kelola } \\
\text { Instansi Dinas } \\
\text { Kesehatan }\end{array}$} & $\begin{array}{l}\text { Nilai } \\
\text { Akuntabilitas } \\
\text { Instansi } \\
\text { Pemerintah }\end{array}$ & 1.121 .330 .000 & 954.812 .500 & 85,15 \\
\hline & & $\begin{array}{l}\text { Persentase Aset } \\
\text { dalam Kondisi } \\
\text { Baik }\end{array}$ & 2.877.248.133 & 2.132.567.107 & 74,12 \\
\hline
\end{tabular}

Sumber: LKIP Dinas Kesehatan Kabupaten Bandung, 2017

Tabel tersebut diatas memberikan informasi bahwa terdapat penyerapan anggaran yang sangat rendah pada sasaran strategis yang kedua yaitu Menurunnya Angka Kesakitan dan Kematian Akibat Penyakit Menular dan Tidak Menular. Indikator Kinerja Angka Kematian Bayi yang hanya terserap 36,68\% menunjukkan bahwa masih adanya pelaksanaan program kegiatan yang kurang efektif dalam menggunakan angggaran yang sudah ditetapkan sebelumnya. Kegagalan dalam penyerapan anggaran tersebut disebabkan oleh adanya keterlambatan juklak dan juknis kegiatan dalam menunjang pelaksanaan kegiatan.

Sehingga dari pagu anggaran belanja langsung sebesar Rp. 365.116.587.042,- yang dianggarkan untuk mencapai target yang ditetapkan berhasil terserap sebesar Rp. 242.916.907.305,26,- sehingga persentase daya serap anggaran belanja langsung Dinas Kesehatan Kabupaten Bandung sampai 31 Desember 2017 adalah sebesar 66,53\% dari anggaran indikatif yang direncanakan. Hal tersebut menunjukkan bahwa perencanaan Dinas Kesehatan Kabupaten Bandung perlu dioptimalkan agar lebih efektif dan efisien dalam meningkatkan kinerja yang mendukung pencapaian Visi Kabupaten Bandung.

Kemudian Pada dinas tersebut diperoleh informasi melalui Laporan Kinerja Instansi Pemerintah (LAKIP) Dinas Kesehatan Kabupaten Bandung pada tahun 2014 sampai dengan 2017, bahwa penyerapan anggaran belanja langsung dari tahun 2014, 2015, 2016 dan 2017 dikatakan masih belum maksimal. Hal tersebut dapat dilihat bahwa pada tahun 2014 penyerapan anggaran belanja langsung sebesar 66,86\%, kemudian pada tahun 2015 sebesar $72,19 \%$, dan pada tahun 2016 sebesar 74,19\%. 
Tabel 1.2

Daftar Realisasi dan Anggaran Belanja Langsung Dinas Kesehatan Kabupaten Bandung

\begin{tabular}{|l|l|l|l|l|l|}
\hline No & Tahun & Anggaran & Realisasi & Persentase & Sisa Anggaran \\
\hline 1 & 2014 & $187.303 .651 .800,-$ & $125.231 .955 .718,-$ & $66,86 \%$ & $62.071 .696 .082,-$ \\
\hline 2 & 2015 & $248.523 .941 .501,-$ & $179.417 .315 .809,-$ & $72,19 \%$ & $69.106 .625 .692,-$ \\
\hline 3 & 2016 & $306.990 .292 .055,-$ & $227.746 .742 .512,49,-$ & $74,19 \%$ & $79.243 .549 .542,51,-$ \\
\hline 4 & 2017 & $365.116 .587 .042,-$ & $242.916 .907 .305,26,-$ & $66,53 \%$ & $122.199 .679 .736,74$ \\
\hline
\end{tabular}

Sumber: LAKIP Dinas Kesehatan Kabupaten Bandung, 2017

Dilihat dari tahun 2014 sampai dengan tahun 2017, anggaran Belanja Langsung pada Dinas Kesehatan Kabupaten Bandung tiap tahunnya mengalami kenaikan alokasi anggaran, dan untuk penyerapan anggaran pada tahun 2014 sampai tahun 2016 mengalami peningkatan dalam persentase, yaitu 66,86\% (2014), 72,19\% (2015), 74,19\% (2016) namun masih terdapat sisa anggaran yang banyak yang tidak dimanfaatkan. Dan pada tahun 2017 persentase penyerapan anggarannya mengalami penurunan menjadi $66,53 \%$. Sedangkan jika dilihat dari sisa anggaran dari tahun ke tahun mengalami peningkatan dan sisa anggaran yang paling tinggi terjadi pada tahun 2017.

Adapun kendala yang dihadapi dalam pencapaian target realisasi anggaran pada Dinas Kesehatan Kabupaten Bandung pada Tahun 2017 adalah:

1. Keterlambatan pelaksanaan koordinasi dan ketersediaan informasi serta mekanisme bantuan dana Provinsi dan Pusat, terutama yang berasal dari Dana Alokasi Khusus (DAK) dan non fisik untuk kegiatan Bantuan Operasional Kesehatan (BOK) dan Jaminan Persalinan (Jampersal) sehingga ada beberapa kegiatan yang sudah direncanakan namun tidak dapat dilaksanakan;

2. Peran serta masyarakat dalam kegiatan kesehatan belum optimal sehingga tidak semua kegiatan yang melibatkan masyarakat dapat terlaksana;

3. Ketidakmampuan aparatur pegawai dalam melakukan pencatatan dan pelaporan keuangan terutama di UPTD pelayanan kesehatan sehingga pertanggung jawaban dan pendokumentasian kurang optimal;

4. Ketidakcakapan aparatur pegawai dalam pelaksanaan program pelayanan kesehatan;

5. Data keuangan, data non keuangan dan data program sebagai bahan penyusunan laporan keuangan belum tepat waktu.

Dengan melihat fenomena penyerapan anggaran belanja langsung yang ada pada Dinas Kesehatan Kabupaten Bandung, maka dari itu penulis tertarik untuk melakukan penelitian tentang: "Analisis Penyerapan Anggaran Belanja Langsung Pada Dinas Kesehatan Kabupaten Bandung Tahun Anggaran 2017”. Sehingga penelitian ini bertujuan untuk menganalisis bagaimana penyerapan anggaran belanja langsung pada Dinas Kesehatan Kabupaten Bandung tahun anggaran 2017. 


\section{Metode Penelitian}

Pendekatan penelitian yang digunakan adalah kualitatif dengan jenis penelitian deskriptif. Peneliti menggunakan metode ini karena relevan dengan permasalahan yang ada dan sesuai dengan rumusan masalah yang ada untuk menggambarkan objek penelitian yang akan diteliti berkaitan dengan penyerapan anggaran. Di mana penelitian ini hanya menggunakan satu variabel tanpa membandingkan dengan variabel lainnya. Penelitian ini menggunakan jenis penelitian deskriptif karena untuk memberikan deskripsi atau gambaran mengenai persoalan, kejadian, aktifitas yang sedang berlangsung pada waktu penelitian dilakukan. Dengan menggunakan pendekatan kualitatif dan metode deskriptif ini peneliti berupaya untuk menguraikan, menggambarkan, mencatat, menganalisis, menginterpretasikan kejadiankejadian dan fakta-fakta yang ditemukan dalam penelitian mengenai analisis penyerapan anggaran belanja langsung pada Dinas Kesehatan Kabupaten Bandung.

\section{Hasil Dan Pembahasan}

Dinas Kesehatan Kabupaten Bandung merupakan salah satu bagian dari Satuan Kerja Perangkat Daerah (SKPD) Pemerintah Kabupaten Bandung yang bergerak di bidang pelayanan kesehatan publik. Untuk melaksanakan tugas dan kewajibannya, Dinas Kesehatan Kabupaten Bandung mendapatkan Pagu Anggaran Belanja Langsung sebesar Rp. 365.116.587.042,-. Pagu anggaran sebesar tersebut digunakan untuk membiayai pelaksanaan program yang ada pada Dinas Kesehatan Kabupaten Bandung Pada Tahun 2017 dan berhasil terserap atau penyerapan anggarannya sebesar 66,53\%. Anggaran Belanja Langsung Dinas Kesehatan Kabupaten Bandung Tahun Anggaran 2017 dapat dilihat berdasarkan unsur-unsur anggaran dari Subagio dalam Tjandra (2009) yaitu:

\section{a. Kebijakan Pemerintah yang Tercermin dalam Angka-Angka}

Aspek pertama dari unsur - unsur anggaran yaitu mengenai kebijaksanaan pemerintah yang tercermin dalam angkaangka. Anggaran merupakan kebijaksaan pemerintah yang tercermin dalam angkaangka. Anggaran Belanja Langsung pada Dinas Kesehatan Kabupaten Bandung Tahun Anggaran 2017 yaitu sebesar Rp.365.116.587.042,-. Anggaran tersebut ditetapkan bukan sembarang dalam arti sebelum angka itu muncul sudah melalui tahapan perencanaan anggaran sampai ditetapkan untuk kemudian dilaksanakan dalam hal mencapai tujuan.

"Proses perencanaan anggaran pasti gak akan lepas dari proses perencanaan sebelumnya dimana kita pasti punya dokumen-dokumen, dimulai dengan dokumen-dokumen perencanaan lima tahunan, berupa kalo di dalam level kedaerahan berupa RPJMD, kemudian untuk level dinas dalam bentuk RENSTRA". (Wawancara pada tanggal 28 Januari 2019).

Jadi, besarnya angka yang ditetapkan dalam anggaran belanja langsung Dinas Kesehatan Kabupaten Bandung Tahun Anggaran 2017 tersebut dihasilkan dari proses perencanaan mulai dari level kedaerahan sampai level dinas. 
Selanjutnya kepala bagian keuangan menjelaskan mengenai anggaran dalam wawancara sebagai berikut:

"Nah penganggaran tahunan itu pasti mengadopsi pada rencanarencana yang telah ditetapkan dalam dokumen-dokumen tersebut yang telah ditetapkan tadi itu. Sehingga pembiayaan itu mengikuti rencana kerja yang akan di laksanakan. Jadi bukan uangnya dulu tapi kegiatannya apa yang akan dikerjakan sehingga muncullah angka besarnya anggaran”. (Wawancara pada tanggal 30 Januari 2019).

Dari informasi tersebut dapat dikatakan bahwa Dinas Kesehatan Kabupaten Bandung telah melakukan proses perencanaan yang panjang untuk menentukan besarnya anggaran yang harus dialokasikan yaitu untuk anggaran belanja langsung pada tahun 2017 sebesar Rp. 365.116.587.042,-.

\section{b. Rencana Pemasukan untuk Membiayai Pengeluaran}

Aspek selanjutnya dari unsur-unsur anggaran yaitu rencana pemasukan untuk membiayai pengeluaran. Untuk menjalankan tugas dan melaksanakan semua program yang sudah ditetapkan oleh suatu organisasi, maka diperlukan biaya pemasukan yang dapat digunakan untuk menunjang pelaksanaan program. Karena tanpa ada pemasukan maka akan sulit untuk menjalankan kegiatan dan mencapai tujuan. Dinas Kesehatan Kabupaten Bandung memiliki pemasukan untuk membiayai pengeluaran dalam setiap program yang ada. Berdasarkan hasil wawancara dengan kepala bagian program sebagai berikut:

"Sumber pemasukan Anggaran Dinas Kesehatan Kabupaten Bandung seperti pemerintah daerah pada umumnya, kita dari berbagai sumber baik berupa APBD, APBN, serta dana bagi hasil, ya itu yang masuk dalam pola yang dikelola langsung oleh pemerintah daerah ya tadi koridornya adalah APBD”. (Wawancara pada tanggal 28 Januari 2019).

Jadi, sumber pemasukan yang diperoleh oleh Dinas Kesehatan Kabupaten Bandung berasal dari APBD, APBN serta dana bagi hasil yang dikelola langsung oleh pemerintah daerah. Dengan dana tersebut dapat dimanfaatkan untuk menyelesaikan permasalahan yang dihadapi masyarakat khususnya dalam bidang kesehatan. Pendapat tersebut diperkuat lagi oleh kepala bagian keuangan dalam wawancara berikut ini:

"UU Kesehatan mengamanatkan bahwa anggaran kesehatan itu minimal 10\% dari APBD, 5\% (di luar gaji) dari APBN. DINKES sudah diangka 20\% dari APBD. UU NO 36 Tahun 2009”. (Wawancara pada tanggal 30 Januari 2019).

Dari informasi tersebut dapat diketahui bahwa sumber pemasukan yang digunakan untuk membiayai semua aktivitas dan kegiatan yang ada pada Dinas Kesehatan Kabupaten Bandung Tahun Anggaran 2017 berasal dari 20\% dana APBD Kabupaten Bandung, ini sesuai dengan UU Kesehatan. 


\section{c. Memuat Data Pelaksanaan Anggaran Satu Tahun Lalu}

Memuat data pelaksanaan anggaran satu tahun lalu merupakan aspek yang penting dari anggaran. Dalam menyusun anggaran untuk tahun selanjutnya, diperlukan dokumen anggaran tahun lalu untuk dijadikan sebagai acuan atau pedoman dalam menyusun anggaran diwaktu yang akan datang, agar sasaran dari program kegiatan yang belum tercapai dapat dilaksanakan di tahun selanjutnya, dan dengan dokumen anggaran tahun sebelumnya dapat diperoleh informasi yang lebih rinci tentang penyusunan anggaran yang akan datang. Hal ini sesuai dengan yang disampaikan oleh kepala bagian program dalam wawancara, yaitu:

"Dokumen anggaran tahun lalu pasti dipakai, tapi dalam hal kegiatan bukan uangnya. Kalau kegiatan yang tahun lalu sekiranya sudah selesai sudah diintervensi dengan anggaran tahun lalu ya sekarang pasti gak akan dikasih anggaran lagi kalau dianggap sudah selesai target sudah tercapai. nah kalo belum selesai tahapannya kan misalnya dalam dokumen lima tahun kan ada pekerjaan yang tidak bisa diselesaikan satu tahun anggaran, sehingga sekarang dilanjutkan lagi”. (Wawancara pada tanggal 28 Januari 2019).

Jadi, dapat diketahui bahwa Dinas Kesehatan Kabupaten Bandung menggunakan data pelaksanaan anggaran atau dokumen anggaran tahun lalu sebagai acuan untuk melihat kegiatan apa saja yang sudah selesai dan sesuai target, lalu kegiatan apa saja yang masih dalam proses pelaksanaan serta kegiatan yang pencapaiannya tidak bisa dicapai dalam waktu satu tahun anggaran. Contohnya pembangunan Puskesmas, jika belum selesai dalam satu tahun anggaran tersebut maka bisa dilanjutkan pada tahun anggaran yang akan datang.

\section{d. Menunjukkan Sektor Yang Diprioritaskan}

Aspek selanjutnya dari anggaran yaitu anggaran harus menunjukkan sektor yang diprioritaskan. Dalam melaksanakan tugas dan tanggung jawabnya, setiap pemerintah baik itu pemerintah pusat maupun pemerintah daerah diharapkan untuk mampu menerima dan melaksanakan seluruh apresiasi dari masyarakatnya, karena tugas pemerintah itu sendiri adalah untuk mensejahterakan masyarakatnya dengan memberikan pelayanan yang terbaik. Oleh sebab itu pemerintah harus mengetahui isu-isu atau masalah-masalah yang sedang dihadapi oleh masyarakat sehingga pemerintah bisa memberikan solusi dari masalah yang sedang dihadapi oleh masyarakat. Dalam hal ini perlu untuk menunjukkan sektor yang diprioritaskan oleh pemerintah agar lebih efektif dan efisien dalam mencapai tujuan.

Dinas Kesehatan Kabupaten Bandung memiliki sektor yang diprioritaskan dalam melaksanakan tugas dan tanggungjawabnya, seperti yang disampaikan oleh kepala bagian program dalam wawancara yaitu sebagai berikut:

"Pasti ada sektor yang diprioritaskan, contoh ya kita itu udah punya beberapa indikator kinerja yang disebut ada indikator kinerja utama ada juga itu dibebani dengan SPM (Standar Pelayanan Minimal). Itu wajib kita anggarkan, karna kalo indikator kinerja utama itu hal yang pasti akan diukur dan harus dicapai karena menyangkut integritas tertentu serta manfaat dari keberadaan institusi itu. kemudian kalau SPM itu amanat Undang-Undang itu hak-hak masyarakat yang wajib dipenuhi oleh institusi. indikator kinerja utama itu dituangkan dalam RPJM, contohnya indeks kepuasan masyarakat bidang kesehatan sama 
satu lagi itu indeks kesehatan. Sedangkan kalo standar pelayanan minimal itu dari pemerintah pusat ada PPnya Peraturan Pemerintah No 2 Tahun 2018. Itu wajib dipenuhi seluruh dinas itu wajib melaksanakan SPM". (Wawancara pada tanggal 28 Januari 2019).

Dengan sektor yang diprioritaskan tersebut diharapkan Dinas Kesehatan Kabupaten Bandung dapat melaksanakan tugas dan tanggungjawabnya dalam memenuhi kebutuhan masyarakat. Sesuai dengan Peraturan Pemerintah No 2 Tahun 2018 tentang Standar Pelayanan Minimal (SPM) yang wajib dilaksanakan oleh pemerintah.

\section{e. Menunjukkan Maju/Mundurnya Pencapaian Sasaran}

Anggaran dibuat dan dilaksanakan untuk menunjukkan maju/mundurnya pencapaian sasaran yang telah ditetapkan. Tujuan pemerintah khususnya pemerintah daerah yaitu memberikan pelayanan yang baik terhadap masyarakatnya. Dengan perencanaan yang telah dibuat dan ditetapkan sebelumnya maka dalam melaksanakan apa yang telah direncanakan harus sesuai dengan apa yang telah direncanakan pula. Kemudian dari situlah diketahui maju atau mundurnya pencapaian sasaran. Pelaksanaan yang baik akan menunjukkan hasil atau pencapaian yang baik pula dan sebaliknya jika pelaksanaan kegiatan tidak baik maka hasil atau pencapaian juga tidak baik.

Dinas Kesehatan Kabupaten Bandung pada Tahun Anggaran 2017 menunjukkan pencapaian sasaran yang baik walau masih terdapat beberapa kegiatan yang belum maksimal, seperti yang disampaikan oleh kepala bagian program dalam wawancara berikut ini:

"Kalau diberbagai indikator ada yang sudah tercapai ada yang tidak, nah kalau tercapai dan tidak tercapai itu kadang-kadang tergantung target yang telah ditetapkan kan. Jadi target itu juga ada yang bisa kita tentukan sendiri ada yang sudah ditetapkan sebelumnya, sebagai contoh yang tidak tercapai itu standar pelayanan minimal yang di PP itu disebutkan capaiannya harus $100 \%$. Yang kita sulit untuk mencapai itu cakupan pelayanan kesehatan usia produktif sesuai standar. Tidak tercapai itu karena sasarannya yang terlalu banyak, kan kalau penduduk kabupaten Bandung 3,6 juta nah penduduk usia produktif 2,5 juta, sebanyak 2,5 penduduk Kabupaten Bandung dalam usia produktif (1559 tahun) harus kami layani sesuai standar. Untuk mencapainya sulit karena terlalu banyaknya target yang ditetapkan". (Wawancara pada tanggal 28 Januari 2019).

Jadi, ada indikator Standar Pelayanan Minimal (SPM) yang masih sulit untuk mencapainya karena terlalu banyak target yang ditetapkan. Itu merupakan salah satu kendala Dinas Kesehatan Kabupaten Bandung dalam melaksanakan SPM yang ditetapkan oleh Pemerintah Pusat. Namun sejauh ini Dinas Kesehatan Kabupaten Bandung telah melaksanakan tugas dan tanggung jawabnya dengan baik dan sesuai prosedur yang ada, hanya saja ada beberapa indikator yang sulit untuk mencapainya. 
f. Petunjuk bagi Pemerintah untuk Melaksanakan Kebijaksanaannya selama Satu Tahun Mendatang

Aspek yang terakhir yaitu anggaran harus dijadikan sebagai petunjuk bagi pemerintah untuk melaksanakan kebijaksanaannya selama satu tahun mendatang. Anggaran yang telah direncanakan dan ditetapkan oleh Dinas Kesehatan Kabupaten Bandung digunakan sebagai petunjuk untuk melaksanakan seluruh program kegiatan selama satu tahun mendatang. Namun, dalam pelaksanaannya masih ada program kegiatan yang terkadang tidak sesuai dengan yang sudah direncanakan, ini dipengaruhi oleh beberapa faktor penyebabnya sesuai yang dijelaskan oleh kepala bagian program dalam wawancara, yaitu:

"Yang biasanya terjadi kalo kita gagal dan tidak sesuai dengan perencanaan sebelumnya itu yang satu adalah top down yang kedua adalah politik. Gagal itu mungkin begini jadi kita sudah menganggarkan sebagai contoh untuk usulan pembangunan polindes atau poskesdes, nah ternyata setelah kita anggarkan pada dokumen anggaran saat kita ingin melaksanakan secara teknis ternyata tanahnya bermasalah kadangkadang gitu, kemudian juga secara teknis kalau di bangun di situ tempatnya jauh dari mana-mana". (Wawancara pada tanggal 28 Januari 2019).

Jadi, masih terdapat kegagalan dalam pelaksanaan kegiatan yang ada pada Dinas Kesehatan Kabupaten Bandung. Namun kegagalan hanya beberapa kali dan tidak sering terjadi. Ini menunjukkan bahwa anggaran dijadikan petunjuk bagi pemerintah khususnya Dinas Kesehatan Kabupaten Bandung untuk melaksanakan kebijaksanaannya selama satu tahun mendatang.

Analisis Penyerapan Anggaran Belanja Langsung Pada Dinas Kesehatan Kabupaten Bandung Tahun Anggaran 2017 dapat dilihat dari indikator - indikator sebagai berikut:

\section{a. Pemberian Kewenangan Kuasa Pengguna Anggaran}

Mengacu pada Permendagri Nomor 21 Tahun 2011, bahwa Kuasa Pengguna Anggaran merupakan pejabat yang diberi kuasa untuk melaksanakan sebagian kewenangan pengguna anggaran dalam melaksanakan sebagian tugas dan fungsi SKPD. Berdasarkan aturan tersebut maka Kuasa Pengguna Anggaran memiliki kewenangan yang ditetapkan oleh Bupati sebagai pemegang kekuasaan pengelolaan keuangan daerah.

Pemberian Kewenangan Kuasa Pengguna Anggaran juga merupakan indikator penyerapan anggaran. Untuk menunjang pelaksanaan kegiatan, Dinas Kesehatan Kabupaten Bandung juga memiliki Kuasa Pengguna Anggaran yang bertanggung jawab atas pemanfaatan anggaran yang ada. Ini sesuai dengan wawancara pada kepala bagian keuangan sebagai berikut:

"Iya ada pemberian kewenangan kepada Kuasa Pengguna Anggaran (KPA) karena anggaran yang ada pada Dinkes juga besar dan dapat dijadikan sebagai ke rentang kendali, sesuai dengan Permendagri Nomor 13”. (Wawancara pada tanggal 30 Januari 2019).

Jadi, Dinas Kesehatan Kabupaten Bandung telah memenuhi aturan yang ada tentang pemberian Kuasa Pengguna Anggaran yang dapat menunjang pelaksanaan kegiatan dan pemanfaatan anggaran, oleh sebab itu maka penyerapan anggaran sudah terealisasi dengan baik dan sesuai apa yang diharapkan. 


\section{b. Batas Waktu Penyelesaian Tagihan}

Indikator selanjutnya dalam penyerapan anggaran yaitu Batas Waktu Penyelesaian Tagihan. Untuk mengetahui mengenai batas waktu penyelesaian tagihan, berikut penjelasan kepala bagian keuangan dalam wawancara, sebagai berikut:

"Sebenarnya kalau aturan itu bahwa pencairan dana untuk membayar tagihan harus sudah ada bukti transaksi, dokumen-dokumen administratifnya, terus kalau belanja modal atau belanja barang dan jasa harus ada serah terima barang dan berita acara, kalau misalnya di pembangunan fisik ada PHO istilahnya, semua itu harus ditempuh dulu. Kalau itu seтиa ada harus segera dicairkan. Jadi kita itu ada ketentuannya seminggu maksimal untuk pencairan. Kalau kita tidak ada yang melewati tahun anggaran. Karena sudah sesuai dengan prosedur tersebut". (Wawancara pada tanggal 30 Januari 2019).

Dari penjelasan tersebut dapat diketahui bahwa batas waktu penyelesaian tagihan itu seminggu paling maksimal dan Dinas Kesehatan Kabupaten Bandung tidak ada yang melewati tagihan tahun anggaran karena sudah sesuai dengan prosedur yang ada.

\section{c. Penerapan Sistem Reward and Punishment}

Dalam organisasi, pemberlakuan sistem reward and punishment merupakan hal yang penting untuk menunjang pencapaian kinerja yang baik serta dapat memotivasi para pegawai agar lebih baik lagi dalam bekerja.

Dinas Kesehatan Kabupaten Bandung juga menerapkan sistem reward and punishment ini, sesuai dengan yang disampaikan oleh kepala bagian keuangan, sebagai berikut:

"Sebenarnya kalau reward and punishment sekarang ada Analisis Jabatan (ANJAB) dan Analisis Beban Kerja (ABK), secara tidak langsung itu merupakan reward and punishment. Jadi apabila dia kinerjanya buruk misalnya tapi tidak secara langsung punishment dari pencairan, misalnya dia tidak pernah ngantor sehingga pekerjaannya tidak dikerjakan, karena dia tidak ngantor berarti absensinya jelek, sehingga tunjangan penghasilannya tidak diberikan, itu kan punishment sebetulnya. Jadi tunjangan berbasis kinerja itu ke sana arahnya. Jadi kalau misalnya dia memang tidak bekerja dengan baik secara tidak langsung dia akan mendapatkan punishment, otomatis cakupan programnya juga tidak baik". (Wawancara pada tanggal 30 Januari 2019).

Dari penjelasan tersebut dapat diketahui bahwa Dinas Kesehatan Kabupaten Bandung secara tidak langsung telah menerapkan sistem reward and punishment untuk mendorong kinerja pegawai agar penyerapan anggaran lebih baik.

\section{d. Peningkatan Sumber Daya Manusia}

Sumber daya manusia merupakan salah satu faktor yang mendukung penyerapan anggaran belanja langsung pada Dinas Kesehatan Kabupaten Bandung. Karena dalam proses penyerapan anggaran dilakukan oleh sumber daya manusia yang diharapkan professional, ahli dibidangnya, berkompeten dan berkualitas sehingga penyerapan anggaran dapat dilakukan 
dengan baik sesuai dengan yang telah direncanakan sebelumnya. Hasil wawancara mengenai sumber daya manusia dengan kepala bagian keuangan, yaitu sebagai berikut:

"Sumber daya manusia kalau memadai dan berkompeten iya, karena harus tersertifikasi. Jadi yang memang dia diberi tugas pasti berkompeten dan bersertifikat. Tetapi dengan jumlah anggaran yang banyak dan jenis pengadaan yang banyak ya masih kurang. Apalagi untuk dipuskesmas sekarang masih sama kita pengadaannya karena mereka tidak ada yang bersertifikasi”. (Wawancara pada tanggal 30 Januari 2019).

Dari informasi tersebut dapat diketahui bahwa Dinas Kesehatan Kabupaten Bandung telah memiliki sumber daya manusia yang berkompeten dan bersertifikasi. Sehingga terpercaya juga dalam melaksanakan tugasnya khususnya dalam pengadaan barang dan jasa.

Selain dari itu, Dinas Kesehatan Kabupaten Bandung juga telah mengadakan pelatihan untuk menunjang peningkatan sumber daya manusia. Sesuai dengan disampaikan kepala bagian keuangan dalam wawancara sebagai berikut:

"Sebenarnya pelatihan sudah dilaksanakan untuk pengadaan barang dan jasa cuman mungkin sulit jadi tidak banyak yang lulus, kemudian yang kedua lebih kearah psikologis mereka memang tidak mau lulus. Karena kalau menjadi pejabat pengadaan barang itu bukan mudah punya resiko. Berapa reward yang dia terima dengan resikonya". (Wawancara pada tanggal 30 Januari 2019).

Pelatihan yang dilakukan tersebut ternyata tidak serta merta membuat sumber daya manusia (pegawai) yang ada pada Dinas Kesehatan Kabupaten Bandung mau untuk menjadi pegawai yang bersertifikasi dalam hal pengadaan barang dan jasa karena mereka sadar akan resiko yang dimiliki jika berda di posisi seperti itu. dan itu menjadi suatu kelemahan pada sumber daya manusianya.

\section{e. Penganggaran yang Tepat dan Ketepatan Waktu Penunjukan Pejabat Perbendaharaan}

Penganggaran yang tepat merupakan hal yang harus dilakukan untuk mendorong penyerapan anggaran. Dibutuhkan perencanaan anggaran yang real dan terencana agar organisasi dapat berjalan dengan baik dalam waktu ke depan. Anggaran belanja langsung suatu organisasi merupakan suatu rencana yang disusun secara sistematis dan terukur dalam bentuk angka yang terdiri dari keseluruhan kegiatan organisasi untuk jangka waktu tertentu dalam satu tahun anggaran.

Dinas Kesehatan Kabupaten Bandung memiliki anggaran belanja langsung yang sudah disusun dengan baik dalam proses perencanaan yang sudah dilakukan sebelumnya. Berikut hasil wawancara dengan kepala bagian keuangan, yaitu:

"Jadi kalau penyusunan anggaran itu memang sudah ada aturannya, penyusunan anggaran itu kalau pengelolaan keuangan ada anggaran, perencanaan anggaran, penatausahaan keuangan, pelaksanaan kegiatan, penyusunan laporan keuangan, itu dalam satu rangkaian. Perencanaan yang sudah kita lakukan itu dari mulai kita membuat Lembaran Kegiatan (LK), kemudian diverifikasi oleh penyusunan 
program lalu dibuatkanlah RKA kemudian DPA kemudian disahkan, udah sesuai. Namun untuk tahun 2017 pengesahan anggaran belum tepat waktu disebabkan kepentingankepentingan yang ada dalam proses pembahasan anggaran”. (Wawancara pada tanggal 30 Januari 2019).

Dari hasil wawancara tersebut dapat diketahui bahwa pada Dinas Kesehatan Kabupaten Bandung anggaran belanja langsung sudah disusun sesuai dengan prosedur dan aturan yang harus dipenuhi, namun waktu pengesahan anggaran tidak dilakukan tepat waktu.

Selanjutnya dalam hal ketepatan waktu penunjukan pejabat perbendaharaan, Dinas Kesehatan Kabupaten Bandung melakukan penunjukan pejabat perbendaharaan atau bendahara pada saat setiap awal tahun anggaran dan dilakukan satu kali dalam satu tahun. Sesuai dengan yang disampaikan oleh kepala bagian keuangan ketika ditanya tentang waktu penunjukan bendahara. Dalam wawancara sebagai berikut:

"Setiap awal tahun, secara umum yang Namanya penunjukan itu dilaksanakan satu tahun sekali atau satu tahun anggaran”. (Wawancara pada tanggal 30 Januari 2019).

Dapat disimpulkan bahwa Dinas Kesehatan Kabupaten Bandung telah menjalankan penganggaran dengan tepat waktu dan penunjukan pejabat perbendaharaan dengan ketepatan waktu pula. Hal ini dapat menjadi pendorong dalam penyerapan anggaran yang ada pada Dinas Kesehatan Kabupaten Bandung.

\section{f. Pemahaman terhadap Ketentuan dan Mekanisme Pengelolaan Keuangan}

Dalam mengelola keuangan agar penyerapan anggaran optimal maka pegawai harus memiliki pemahaman terhadap ketentuan dan mekanisme pengelola keuangan, khususnya bagi pegawai yang terlibat dalam pengelolaan keuangan.

Memahami ketentuan dan mekanisme pengelolaan keuangan bertujuan agar anggaran yang telah dialokasikan dapat digunakan dengan sebaik-baiknya secara efektif dan efisien serta mencapai tujuan yang telah ditetapkan sebelumnya.

Dalam mengelola keuangan ini yang di dalamnya berhubungan dengan anggaran serta penyerapan anggaran, pegawai yang terlibat dalam pengelolaan keuangan pada Dinas Kesehatan Kabupaten Bandung telah memahami ketentuan dan mekanisme pengelolaan keuangan tersebut. Seperti yang dijelaskan oleh kepala bagian keuangan dalam wawancara, sebagai berikut:

"Ya pegawai yang terlibat dalam pengelolaan keuangan sudah memahami ketentuan dan mekanisme yang ada untuk mengelola keuangan, dan sesuai dengan SK”. (Wawancara pada tanggal 30 Januari 2019).

Dari informasi tersebut dapat diketahui bahwa Dinas Kesehatan Kabupaten Bandung dapat dikatakan telah melaksanakan pengelolaan keuangan sesuai dengan ketentuan dan mekanisme yang ada seperti. Kemudian kepala bagian program menjelaskan bahwa ketentuan dan mekanisme dalam pengelolaan keuangan pada Dinas Kesehatan Kabupaten Bandung di dalamnya memuat tentang hal - hal sebagai berikut seperti yang dijelaskan dalam wawancara sebagai berikut: 
"Jika ketentuan dan mekanisme pengelolaan keuangan itu salah satunya terdiri dari transparansi dan akuntabilitas anggaran, disiplin anggaran, keadilan anggaran, efisiensi dan efektivitas anggaran, keuangan disusun dengan pendekatan kinerja". (Wawancara pada tanggal 28 Januari 2019).

Jadi, pengelolaan keuangan pada Dinas Kesehatan Kabupaten Bandung di susun dengan pendekatan kinerja agar program kegiatan yang telah dibuat dapat dilaksanakan dengan baik serta efektif dan efisien. Dengan adanya pegawai yang telah memahami ketentuan dan mekanisme pengelolaan keuangan maka penyerapan anggaran dapat terealisasi dengan optimal sesuai dengan yang diinginkan.

\section{g. Mekanisme Penyelesaian Pencairan Dana yang Cepat dan Tepat}

Mekanisme penyelesaian pencairan dana yang cepat, tepat, transparan dan akuntabel merupakan indikator yang penting dalam penyerapan anggaran. Pencairan dana harus dilakukan dengan cepat dan tepat karena jika pencairan dana mengalami keterlambatan maka akan berdampak terhadap pelaksanaan program kegiatan yang ada, karena setiap program kegiatan yang akan dilaksanakan menggunakan dana yang seharusnya dapat dicairkan tepat waktu.

Mekanisme pencairan dana harus ditempuh dengan baik sesuai dengan waktu yang telah ditentukan. Kepala bagian keuangan menjelaskan mengenai pencairan dana dalam wawancara sebagai berikut:

"Karena kita menggunakan aplikasi SIMDA, jadi untuk pencairan itu seminggu waktunya, itu sudah aturannya. Kalau lebih dari seminggu misalnya ada kesalahan bolak balik terus, nanti ada kadaluarsanya dan SPM (suratperintah membayar) nya harus dari awal lagi. Jadi kita itu ada ketentuannya seminggu maksimal untuk pencairan". (Wawancara pada tanggal 30 Januari 2019).

Dari informasi tersebut diketahui bahwa pencairan dana pada Dinas Kesehatan Kabupaten Bandung memiliki batas waktu satu minggu jika lebih dari waktu tersebut maka prosesnya dari awal lagi ada kadaluarsanya.

Namun, pengajuan pencairan dana tidak bisa dilakukan apabila pengajuan bulan sebelumnya belum mencapi $70 \%$, jadi dapat dikatakan bahwa pencairan dana sebelumnya harus sudah menempuh $70 \%$ proses yang harus ditempuh untuk memenuhi persyaratan baru selanjutnya boleh mengajukan pencairan dana yang lainnya. Hal ini sesuai dengan yang dijelaskan oleh kepala bagian program dalam wawancara berikut ini:

"Pengajuan pencairan dana bisa dilakukan apabila pertanggung jawaban bulan sebelumnya sudah ada $75 \%$. Kalau misalnya yang lalu melaksanakan kegiatan tapi dia belum melakukan pertanggung jawaban, jadi gak bisa dia nyairin dana. Jadi kita uang diganti surat pertanggung jawaban”. (Wawancara pada tanggal 28 Januari 2019).

Dinas Kesehatan Kabupaten Bandung telah menempuh prosedur yang sesuai dalam hal pencairan dana, dilakukan tepat waktu dan tidak pernah terlambat. Seperti yang disampaikan kepala bagian program dalam wawancara berikut: 
"Pencairan dana tidak pernah terlambat, semua tepat waktu. karena semua sudah ada sistemnya, jadi semua bisa dilakukan asal sesuai dengan prosedur yang ada." (Wawancara pada tanggal 28 Januari 2019).

Jadi, dapat disimpulkan bahwa Dinas Kesehatan Kabupaten Bandung sudah melakukan dengan baik dalam hal pencairan dana dan dapat mendukung terlaksananya setiap program kegiatan dengan baik serta penyerapan anggaran dapat terserap dengan optimal pula.

\section{Simpulan}

Berdasarkan pada hasil dan pembahasan penelitian, bahwa diantara indikator dari penyerapan anggaran belanja langsung pada umumnya sudah berjalan dengan baik. Namun, masih ada beberapa hal yang perlu ditingkatkan lagi seperti misalnya mengenai pengesahan anggaran yang belum tepat waktu, kurangnya kemampuan dan kapasitas aparatur pegawai, dan masih ada program yang belum tercapai secara efektif dan efisien sehingga berpengaruh terhadap penyerapan anggaran belanja langsung yang belum optimal. Sehingga Dinas Kesehatan Kabupaten Bandung harus melakukan upaya untuk meningkatkan dan mengoptimalkan penyerapan anggaran dengan cara melakukan pengesahan anggaran secara tepat waktu, mengajukan penambahan jumlah pegawai dan melakukan sosialisasi kepada pegawai mengenai anggaran yang akan digunakan dalam melaksanakan setiap program kegiatan yang sudah ditetapkan sebelumnya agar penyerapan anggaran belanja langsung dapat terserap dengan optimal.

\section{Referensi}

Almi, F. (2018). Analisis Faktor-Faktor yang Mempengaruhi Penyerapan Anggaran Pada Pemerintah Kabupaten/Kota Di Provinsi Sumatera Utara.

Anggara, S. (2012). Ilmu Administrasi Negara. Bandung: CV. Pustaka Setia

Anggara, S. (2015). Metode Penelitian Administratif. Bandung: CV. Pustaka Setia

Anggara, S. (2016). Administrasi Keuangan Negara. Bandung: CV. Pustaka Setia

Bastian, I. (2006). Akuntansi Sektor Publik. Jakarta: Erlangga

Djafar, M.S. (2017). Hukum Keuangan Negara, Teori dan Praktik. Jakarta: PT. Raja Grafindo Persada

Halim, A., Iqbal, M. (2012). Pengelolaan Keuangan Daerah. Yogyakarta: UPP AMP YKPN

Halim, A. (2014). Manajemen Keuangan Sektor Publik. Jakarta: Salemba Empat

Heriyanto, H. (2012). Faktor-Faktor yang Mempengaruhi Keterlambatan Penyerapan Anggaran Belanja Pada Satuan Kerja di Kementrian, Lembaga di Wilayah Jakarta.

Lexy, J. M. (2011). Metode Penelitian Kualitatif. Bandung: PT. Remaja Rosdakarya

Pasolong, H. (2013). Teori Administrasi Publik. Bandung: Alfabeta

Peraturan Menteri Keuangan Nomor 94/PMK.05/2009, BAB 1 Pasal 1 
Peraturan Menteri Dalam Negeri Nomor 13 Tahun 2006 (mengalami perubahan peraturan Menteri Dalam Negeri Nomor 21 Tahun 2011)

Peraturan Menteri Keuangan 49/Peraturan Menteri Keuangan. 02/2011 Peraturan Presiden No. 54 Tahun 2010 Peraturan Menteri Keuangan No. 170/Peraturan Menteri Keuangan. 05/2010 Peraturan Menteri Keuangan No. 38/Peraturan Menteri Keuangan. 02/2011

Priatno. (2013). Analisis Faktor-Faktor yang Mempengaruhi Penyerapan Anggaran Pada Satuan Kerja Lingkup Pembayaran KPPN Blitar.

Mahmudi. (2010). Manajemen Keuangan Daerah. Jakarta: Erlangga

Mahmudi. (2016). Analisis Laporan Keuangan Pemerintah Daerah. Yogyakarta: UPP STIM YKPN

Mardiasmo. (2009). Akuntansi Sektor Publik. Yogyakarta: Penerbit ANDI

Silalahi, U. (2011). Studi Tentang Ilmu Administrasi, Konsep Teori dan Dimensi. Bandung: Sinar Baru Algensindo

Silalahi, U. (2012). Metode Penelitian Sosial. Bandung: Refika Aditama

Sugiyono. (2013). Memahami Penelitian Kualitatif. Bandung: Alfabeta

Tjandra, W. R. (2009). Hukum Keuangan Negara. Jakarta: Grasindo 